
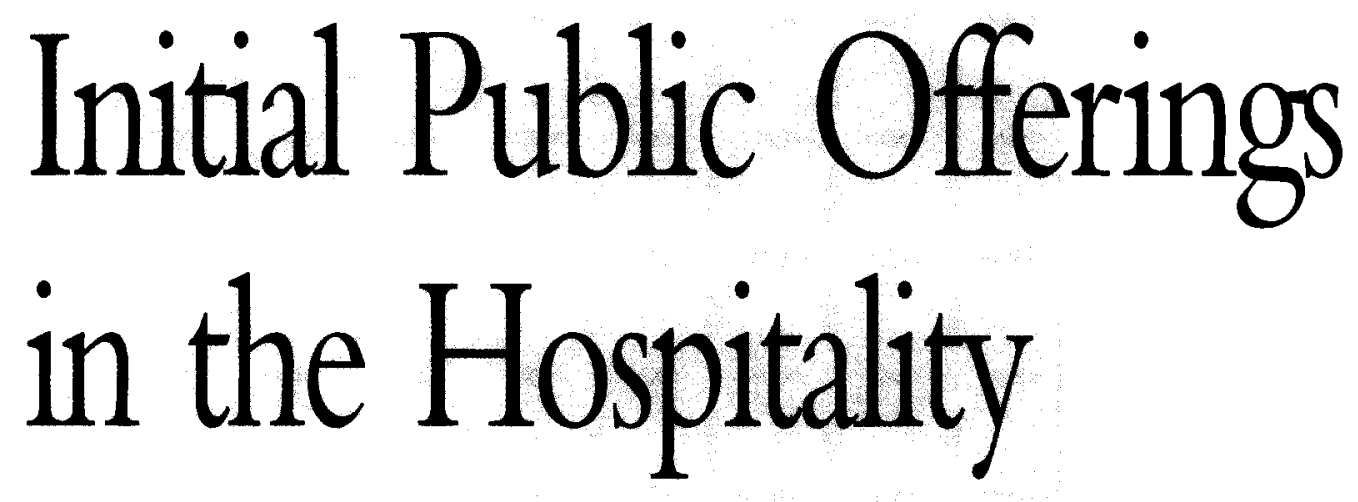

Industry-

\section{Underpricing and Overperformance}

by Linda Canina
Underwriters may view the primary issue of most hotel and casino stocks as more risky than stocks of new companies generally. Still, newly issued stocks of hospitality companies have generally outperformed the market in their first year. he

he number of initial public offerings of stock (IPOs) in hospitality companies has increased substantially in recent years. From 1991 through 1994 an average of 16 hospitality companies per year have gone public, compared to an average of just under seven hospitality IPOs per year from 1979 to 1990. In 1992 numerous restaurant chains went public, while casinos rushed to the market in 1993. What's noticeable about these transactions is that for many of them the offering price is

Linda Canina, Ph.D., is an assistant professor of finance at Cornell's School of Hotel Administration.

(C) 1996, Cornell University 
substantially lower than the first day's closing price in the secondary market. The average initial-day return for all hospitality issues is 16.32 percent, as compared to 15.26 percent in the overall IPO market. ${ }^{1}$ That is not a large difference, but as I will explain, certain industry segments encounter considerable underpricing.

Moreover, on average, hospitality IPO investors earn a higher firstyear return than other IPO investors. During the period of my study, hospitality investors earned an average excess return of 14.11 percent, relative to the Standard and Poor's average of 500 stocks (S\&P 500), in the year following the IPO. In contrast, the average IPO return for the overall IPO market was less than the return on the S\&P 500. Examining restaurant and lodging-casino IPOs separately, lodging-casino IPOs are underpriced more than the overall IPO market, although the underwriters considered to be aboveaverage in reputation underprice their IPOs by a smaller amount than underwriters who are lessestablished.

This paper analyzes the pricing and long-run performance of initial public offerings of stock in hospitality companies, and compares those results to the overall market for IPOs. This comparison is useful both to entrepreneurs who are considering making an initial stock offering and to investors who might wish to purchase newly issued stock. Sellers can use the information to choose an underwriter and to evaluate the performance of investment banks in marketing and pricing IPOs. Investors can gauge how to maximize their expected return per unit of risk. I start by describing the process of going public and then

\footnotetext{
' The initial-day return is the difference between the closing price and the offer price as a percentage of the offer price, at the close of the first day of trading.
}

present the main theoretical explanations of IPO underpricing. These explanations provide a framework for comparing underpricing and long-run performance of hospitality-company IPOs with the overall IPO market's performance. I analyze the relationship of the initial-day return and risk with the long-run performance of IPOs. As an instructive case, I also note the performance of one of the most famous and successful IPOs in the hospitality industry, that of Boston Chicken.

\section{Going Public}

Most companies get their initial equity capital from a small number of investors. ${ }^{2}$ This form of financing is relatively illiquid, however, as there is no ready market to accommodate those investors who later wish to sell their ownership share of the company. If a company prospers and needs additional equity capital, its owners may eventually decide to sell stock shares to a large number of investors in a public offering. Compared to privately held investments, going public allows the company to raise capital on more favorable terms, makes capital more readily available, allows the original owners to diversify their holdings, and provides management and shareholders with a gauge of the firm's value based on the publicly traded price.

By making the decision to go public, the would-be issuer of stock is deciding to sell a portion of the firm. It stands to reason that the principals want to receive as much money as possible in return for a share of the company. The price at which the company can trade ownership for cash depends on overall

\footnotetext{
For example, the New England Applebee's franchisee started with an investor pool of two, the owner and one financial backer. See: Michael L. Oshins, "'Skip' Sack and Applebee's: How Pub Ventures Went Public," Cornell Hotel and Restaurant Administration Quarterly, Vol. 37, No. 3 (June 1996), pp. 55-63.
}

market conditions, the firm's specific situation, and the policies of the investment bankers underwriting the issue.

New issuers search for the best underwriter and the most favorable conditions possible. A firm that wants to go public seeks the assistance of an underwriter or syndicate of underwriters. An IPO is the result of a match between the issuer and the underwriter. The issuer prefers the most prestigious underwriter possible - that is, a firm known for bringing high-quality companies to market. The underwriting firm's notoriety provides a favorable signal to the market. Prestigious investment banking firms, however, remain that way only by carefully choosing the firms they agree to underwrite, often refusing speculative issues.

Best efforts. The offering can be made by either of two methods, "best efforts" or "firm commitment." In best-efforts contracts, the issuer and underwriter negotiate an offering price. The underwriter then uses its best efforts to raise all of the desired capital at the negotiated price, usually receiving a percentage of the capital raised as its fee. If there is not enough demand at the established price, the offer is withdrawn from the market and the issuer raises no capital. Moreover, it is unlikely that a second offering will be made at a lower price. The best-efforts offering minimizes the risk faced by the underwriter and leaves most of the risk to be borne by the issuer.

Firm commitment. In the more-common firm-commitment offering, by contrast, the underwriter guarantees that a specific amount of capital will be raised. In effect, the underwriter buys all of the stock issued at an agreed-upon price (with a price spread intended to compensate the underwriter) and is then responsible for selling it all. 
The underwriter may later reduce the public-offering price to clear the market, but nonetheless delivers to the issuer the entire sum that was originally specified. In a firmcommitment offering, then, it is crucial to the underwriter that the initial price be set appropriately.

Both the issuer and the underwriter of an IPO must comply with the Securities Act of 1933, which requires disclosure of certain information to potential investors and gives them the right to sue if there is misleading information or material omission of fact. The restrictions are stricter for offerings greater than $\$ 7.5$ million in gross proceeds (known as S-1 offerings, after the code section that pertains to them) than they are for those of less than $\$ 7.5$ million ( $\mathrm{S}-18$ offerings). Offerings of less than $\$ 1.5$ million in gross proceeds are eligible for their own treatment under the act's Regulation A, which involves even fewer disclosure requirements.

Regulations promulgated by the Securities and Exchange Commission (SEC) under the 1933 act require the underwriter, after investigating the issuing firm, to file specific information (e.g., type of business, nature of security, financial statements) in a preliminary prospectus. Then there is a period of at least 20 days, during which the SEC reviews the submitted material. During this "cooling off" period, the underwriter surveys the market and sends information to prospective investors.

In a firm-commitment offering, investors are asked to indicate their willingness to purchase shares at some price (i.e., to "circle" their demand). The underwriter uses the responses to set the offering price. The final price is usually set at a pricing meeting the afternoon before the formal offering.

Setting an appropriate price is crucial to a successful IPO. Even after the underwriter surveys the market and investigates the issuer, however, considerable uncertainty remains about how the broad market will receive the issue. The difficulty in pricing arises from the fact that IPO firms, by definition, have no price history. A final point regarding the IPO process is that the investors who have the first chance at the stock are those who are invited by the underwriter. The general public is usually in a secondary position of buying stock from the investors who, in turn, purchased it at the offering price set by the underwriter. This point is important in considering the potential gains of would-be IPO investors.

\section{IPO Underpricing}

While managers of a firm going public are eager to secure the highest possible price for their stock, the underwriters of a firm-commitment offering are likely to be cautious because they will be left with any unsold stock if they overestimate investor demand at a given price. As a result, underwriters typically try to underprice the IPO. Underpricing, they argue, is necessary to reduce the cost of marketing the issue to customers and to tempt investors to buy the stock. The accompanying sidebar on Boston Chicken's IPO gives an example of underpricing.

IPO underpricing is a welldocumented phenomenon. ${ }^{3}$ An historical analysis published in 1994, for example, found that the average first-day IPO return was 15.26 percent in the years $1960-1992 .{ }^{4} \mathrm{Sev}-$

\footnotetext{
"Among the first to document apparent underpricing were: D. Logue, "On the Pricing of Unseasoned Equity Issues, 1965-69," Journal of Financial and Quantitative Analysis, Vol. 8 (1973), pp. 91-103; and Roger Ibbotson, "Price Performance of Common Stock New Issues," Journal of Financial Economics, Vol. 2 (1975), pp. 235-272.

+ Roger G. Ibbotson, Jody L. Sindelar, and Jay R. Ritter, "The Market's Problems with the Pricing of Initial Public Offerings," Journal of Applied Corporate Finance, Vol. 7 (1994), pp. 66-74
}

eral reasons have been proposed to explain why a firm would willingly underprice its securities and thereby limit the funds received for selling a share of the company. The two main theoretical explanations are the winner's curse ${ }^{5}$ and signalingbased models. ${ }^{6}$

Winner's curse. The winner's curse model is drawn from auctions. The highest bidder in an auction for a given item is the participant who places the highest value on the auctioned object. The winner's curse proposes that the winning bidder has an overly optimistic assessment of the object's true value. By winning the auction, according to this logic, one has overpaid for the item. In the case of IPOs, the ability to purchase an allotment of shares may signal that the stock is overpriced. Otherwise, knowledgeable buyers would have subscribed the entire issue.

For stock issues, the winner's curse concept is based on the same idea that some investors are less informed than others. Unless those less-expert investors can spot which issues are underpriced, the uninformed investors are likely to subscribe a small proportion of the cheap issues (compared to knowledgeable investors) and a large proportion of the expensive ones. Here's why: If an issue is underpriced, both informed and unin-

\footnotetext{
"K. Rock, "Why New Issues are Underpriced," Journal of Financial Economics, Vol. 15 (1986), pp. 187-212; R. Beatty and Jay Ritter, "Investment Banking, Reputation, and the Underpricing of Initial Public Offerings," Journal of Financial Economics, Vol. 15 (1986), pp. 213-232; and R. Carter and S. Manaster, "Initial Public Offering and Underwriter Reputation," Joumal of Finance, Vol. 45 (1990), pp. 1045-1067.

"F. Allen and G. Faulhaber, "Signaling by Underpricing in the IPO Market," Journal of Financial Econonics, Vol. 23 (1989), pp. 303-323; M. Grinblatt and C. Hwang, "Signaling and the Pricing of New Issues," Joumal of Finance, Vol. 44 (1989), pp. 393-420; and I. Welch, "Seasoned Offerings, Imitation Costs and the Underpricing of Initial Public Offerings," Journal of Finance, Vol. 44 (1989), pp. 421-449.
} 
formed investors will want to buy it. The uninformed investors are purchasing IPO stocks more or less indiscriminately, while the informed investors recognize an underpriced stock as a wise investment. Because everyone wants some of the underpriced stock, the underwriters will not have enough stock to go around, and both types of investors are likely to get only a small share of a hot issue. If the stock is overpriced, on the other hand, informed investors are unlikely to want it and the underwriter will be only too delighted to sell it to the uninformed. When the uninformed investor "wins" and gets her entire allocation in this scenario, it may be because those who knew betterthe informed-avoided the issue.

Having been burned enough times, the uninformed investors will eventually stop subscribing to IPOs altogether, making it difficult for the underwriters to place their stock. To counteract that possibility, the underwriter must price the stock low enough for the uninformed investor to make money on enough investments to keep her in the market.

(Most investors recognize that some portions of a portfolio will lose money, while others will do well.) Since uninformed investors will subscribe to the issues only if there is substantial underpricing, the only way underwriters can counteract the winner's curse and attract the average investor is to underprice new issues (on average) so that this investor still makes a profit.

One of the implications of the winner's curse model is that riskier issues should have, on average, greater underpricing. Two different studies found that the greater an investment-banking firm's prestige the lower the risk of the IPOs with which the firm is associated. ${ }^{7}$ To

\footnotetext{
${ }^{7}$ See: Rock, pp. 187-212; and Carter and Manaster, pp. 1045-1067.
}

preserve their reputations, prestigious underwriters screen the firms that go public and select the lessrisky ones by using information unavailable to the general public. This, in turn, reduces the uncertainty and information asymmetry between informed and uninformed investors. Investors know that they can limit their risk by subscribing to issues of reputable investment banks. Consequently, the underwriters feel less obligation to underprice wellchosen issues to attract investors, and the initial-day return should be lower for screened issues than for those that the underwriters regard as more risky. As a result, the degree of underpricing and future performance should be related to the reputation of the underwriter. I examine this relationship below.

Signaling. The other main explanation for underpricing a stock issue is that price is a signaling device. One researcher conjectured that new issues may be underpriced to "leave a good taste in investors' mouths." 8 Picking up on that thread, other studies hypothesized that the owner's incentive to leave a good taste with investors is due to the possibility of the owner's subsequently coming back to the market for the sale of additional securities on more favorable terms. ${ }^{9}$ That is, the underpriced new issues are said to "leave a good taste" with investors (because the investors profit from them), allowing companies to sell future offerings at a higher price than would otherwise be the case.

\section{Sample Description and Empirical Results}

My sample firms were obtained from the annual editions of the Directory of Corporate Financing and from Securities Data Company

\footnotetext{
'Ibbotson (1975), p. 270.

"See: Allen and Faulhaber, pp. 303-323; Grinblatt and Hwang, pp. 393-420; and Welch, pp. $421-449$.
}

(SDC). I selected firms for analysis from the list of corporate securities offerings if (1) the firm's primary business was in the hospitality industry (SIC codes 5812 or 7011); (2) they made a firm-commitment offering of at least $\$ 1$ per unit; (3) the unit contained only a single share of stock (no warrants attached) $;^{10}(4)$ the issue was an initial public offering; and (5) the firm was subsequently listed on the University of Chicago Center for Research in Security Prices (CRSP), NASDAQ, American Stock Exchange (AMEX), or New York Stock Exchange (NYSE) daily tapes. A total of 143 firm offerings met all five requirements.

The initial return was calculated using the offer price and the firstday closing price. It is defined throughout this paper as:

$$
\begin{gathered}
\text { initial- } \\
\text { day } \\
\text { return }
\end{gathered}=\frac{\begin{array}{c}
\text { closing price on first day of } \\
\text { trading }- \text { offer price }
\end{array}}{\text { offer price }}
$$

The offer price is taken from the Directory of Corporate Financing and from SDC. The first-day closing price is taken from the 1994 CRSP tapes when available; otherwise, it is collected from the Wall Street Journal.

The long-run performance was the one-year excess return of the stock compared to the S\&P 500's return for the same period, calculated as the stock's geometric return starting with the day after the firm went public, minus the S\&P 500 geometric market return for the same period. In each case I recorded the IPOs' lead underwriter, as supplied by SDC. This sample involved 77 different underwriters. In nine transactions just one underwriter leads, two underwriters lead in approximately six of the transactions,

\footnotetext{
11) Purchasing a warrant gives the investor the right to exchange the warrant for stock in the company when the stock is issued. Warrants are traded like stock shares; that is, the prices of both vary according to market demand.
} 


\section{Boston Chicken's IPO}

Gauging by the firm's reception in the market, Boston Chicken (which operates and franchises Boston Market restaurants) launched one of the most successful IPOs of the past three years. This transaction demonstrates the characteristics of a successful IPO: an easily understood product, an impressive management résumé, a well-planned "road show" (to inform and encourage investors), and a reputable underwriter, the firm of Merrill Lynch.

In addition, Boston Chicken's timing was impeccable and demand was high, partly because the IPO market was in a hot phase. In the offering, the orders placed by individual investors went unfilled (as often happens). Fund managers snapped up the IPO, and individual investors could buy shares only after the stock started trading-at considerably higher prices than the offering price.

On November 8, 1993, Boston Chicken offered 1.9 million shares at $\$ 20$ per share. In the secondary market, trading started at $\$ 45.25$ per share, reached a high of $\$ 51$, and closed at $\$ 48.50$. Boston Chicken made IPO history by soaring nearly $\$ 30$ above its initial price, or about 143 percent, in one day. (It was not until early 1996 that this performance was matched, when Netscape's IPO achieved similar numbers.)

Boston Chicken raised $\$ 38$ million from its IPO. However, by the end of the first trading day, the stock was valued at $\$ 92$ million. Therefore, Merrill Lynch underpriced the offering by $\$ 54$ million. Such underpricing benefits the investor at a cost to the issuing firm and to the benefit of the underwriter, which makes certain of selling its shares. The greater the underpricing, the less money the issuer receives for the portion of the company sold. Thus, underpricing represents an indirect cost of issuing new securities. In this case, the cost was high.

One year later, Boston Chicken was trading at $\$ 38.25$ (adjusted for stock splits). This represents a yearly return of 91.25 percent based on the offer price, or -21.1 percent based on the closing price on the first day of trading in the secondary market. The annual return on the S\&P 500 over this period was about 1.51 percent. The primary investors outperformed the S\&P 500 , but the secondary investors who had bought it at the closing price on the first day of trading clearly underperformed the S\&P 500 .

This example is typical-on average, the offering price is lower that the closing price on the first day. Thus, subscribers earn an extraordinary return if they sell early. However, over a holding period of a year, the investment does not outperform the S\&P 500, based on the closing price in the secondary market.

Underpricing represents a cost to the existing owners, since the new investors are allowed to buy shares in the firm at a favorable price. The cost of underpricing can be very large as was the case with Boston Chicken.-L.C. and nine underwriters lead in three or four transactions. The variable of underwriter reputation was based on rankings supplied by SDC. Its rankings are based on the value of the IPOs underwritten by the investment bank as of the end of 1994.

\section{Many Happy Returns...}

The average return for the first trading day for the 143 hospitality firms in my sample is 16.32 percent (see Exhibit 1). This initial-day return is insignificantly greater than the average initial-day return of 15.72 percent for the overall IPO market in the same 1979-1994 period. ${ }^{11}$ The range of initial returns in the hospitality industry is dramatic, with a minimum first-day return of $\mathbf{- 4 3 . 7 5}$ percent and a maximum of 150 percent. Nearly 76 percent of the firms experienced positive first-day returns, and 12.6 percent incurred negative returns, while 11.4 percent showed no price movement at all. On average, the degree of underpricing of hospitality-industry IPOs was similar to the level of underpricing in the market as a whole.

The dollar size of the IPO also varies greatly across the sample. The mean dollar value of each transaction is $\$ 20.22$ million, but the IPOs range between $\$ 1.5$ million and $\$ 294$ million. The average size of the hospitality-company offerings is less than the average size in the overall market, which is about $\$ 30$ million.

\section{...But Not All Are Happy}

The IPO market experiences hot and cold cycles. That is, the number of offerings varies substantially across different time periods. The overall market, for example, recorded 198 offerings in 1982 versus 848 offerings in $1983 .{ }^{12}$ To identify whether there are similar cycles in the hospi-

\footnotetext{
11 See: Ibbotson, Sindelar, and Ritter (1994), pp. 66-74.

12 Ibid.
}

tality industry, I categorized the data sample by year. As shown in Exhibit 2 , the number of offerings in the hospitality industry varied by year, from a low of one in 1980 to a high of 23 in 1993. The table also shows the great variation in the average initial return across years, from a low of -3.58 percent in 1990 to 57.38 percent in 1979. Most of the time, the average initial return is positive. In fact, the average initial return is positive in 14 out of the 16 years in the sample period.

The table in Exhibit 2 shows that the hospitality industry participates in the hot and cold cycles that characterize the general market. For example, 1991-1994 was a hot cycle for both. The mid-1980s was also a hot period (1983-1987 for the general market and 1981-1986 for the hospitality industry). The mean number of offerings per year during a hot cycle was 12.5 compared to only three during cold cycles.

Ibbotson, Sindelar, and Ritter twice demonstrated that for the entire market, hot cycles are associated with relatively high average initial returns and cold cycles with lower average initial returns. ${ }^{13}$ This implies that firms that issue shares during high-volume periods typically experience high initial price run-ups. In other words, periods of high volume are associated with periods of high discounts in the primary market.

On average, however, that relationship did not appear to hold for hospitality firms (see Exhibit 3). In fact, the opposite was true: the average initial return was lower during hot cycles (16.21 percent) and higher during the cold cycles (17.11 percent). ${ }^{14}$

\footnotetext{
${ }^{13}$ Roger G. Ibbotson, Jody L. Sindelar, and Jay R. Ritter, "Initial Public Offerings," Joumal of Applied Corporate Finance, Vol. 1 (1988), pp. 37-45; and Ibbotson et al. (1994), pp. 66-74.

${ }^{1+}$ The difference between the average initial return in the two cycles is insignificantly different from zero.
} 


\section{Casinos, Hotels, and Restaurants}

To gain a better understanding of the nature of underpricing among hospitality companies, I divided the sample into restaurants (SIC code 5812) and hotels and casino-hotels (SIC code 7011). This allowed me to investigate whether the characteristics of lodging and casino IPOs are different from those of restaurant IPOs.

The differences between the two industry divisions are dramatic, as shown in Exhibit 4. The average initial return for lodging-casino properties (22.46 percent) is significantly higher than for restaurants (14.62 percent). In addition, the average size of hotel and casino offerings - $\$ 43.46$ million-is substantially greater than for the restaurant IPOs-at $\$ 13.80$ million. Moreover, the number of restaurant IPOs is four times greater than the number of lodging-casino IPOs.

Until recently, the IPO activity in lodging-casino properties constituted a small but steady stream.

IPOs have only recently become popular in the lodging-casino segment. In fact, 17 out of the 31 IPOs were issued in 1992-1994, or just three years of the 16-year sample. It is noteworthy that the level of underpricing for the lodging-casino IPOs consistently fell during this period (as gauged by the plunge in initial-day returns). The 1992-1994 hot cycle for lodging-casino IPOs coincided with the industry's economic recovery. Restaurant IPOs, on the other hand, came in batches. Ninety percent of all restaurant IPOs occurred during the hotcycle periods of 1981-1986 and 1991-1994.

Blowing hot and cold. The pattern of initial-day returns in hot and cold cycles is mixed in the two hospitality-industry segments. For restaurants, the hot cycle is associated with high average initial returns and the cold cycle with low

\section{Exhibit 1}

Initial-day return and size of hospitality IPOS

\begin{tabular}{lccc} 
& Initial-Day Return (percent) & & IPO Size (\$ millions) \\
\cline { 2 - 2 } Mean & 16.32 & 20.22 \\
Minimum & -43.75 & 1.50 \\
Maximum & 150.00 & 294.00
\end{tabular}

Based on 143 observations between 1979 and 1994 .

For all exhibits, the initial-day return is defined as: initial-day return $=$ closing price on first day of trading - offer price offer price

The IPO size is defined as the offer price times the number of shares offered.

\section{Exhibit 2}

\section{Hospitality IPOs compared with the overall IPO market}

\begin{tabular}{cc|c|c|c|c}
\multicolumn{4}{c}{} & \multicolumn{3}{c}{ Hospitality Industry } & \multicolumn{2}{c}{ Overall Market } \\
\cline { 2 - 3 } & Number & $\begin{array}{c}\text { Average } \\
\text { initial-day } \\
\text { rear }\end{array}$ & $\begin{array}{c}\text { Average } \\
\text { IPO size } \\
\text { (\$ millions) }\end{array}$ & $\begin{array}{c}\text { Number } \\
\text { of IPOs }\end{array}$ & $\begin{array}{c}\text { Average } \\
\text { initial-day } \\
\text { return }\end{array}$ \\
\hline 1979 & 3 & $57.38 \%$ & $\$ 42.10$ & 103 & $24.61 \%$ \\
1980 & 1 & 1.48 & 4.10 & 259 & 49.36 \\
1981 & 9 & 12.46 & 7.71 & 438 & 16.76 \\
1982 & 8 & 8.74 & 18.23 & 198 & 20.31 \\
1983 & 17 & 9.85 & 14.51 & 848 & 20.79 \\
1984 & 8 & 5.31 & 16.21 & 516 & 11.52 \\
1985 & 8 & 9.17 & 9.18 & 507 & 12.36 \\
1986 & 11 & 14.35 & 5.69 & 953 & 9.99 \\
1987 & 3 & -0.57 & 21.77 & 630 & 10.39 \\
1988 & 2 & 57.69 & 3.60 & 435 & 5.27 \\
1989 & 6 & 5.24 & 19.22 & 371 & 6.47 \\
1990 & 3 & 3.58 & 10.10 & 276 & 9.47 \\
1991 & 10 & 21.31 & 27.59 & 367 & 11.83 \\
1992 & 17 & 20.35 & 25.36 & 509 & 10.90 \\
1993 & 23 & 28.37 & 39.97 & NA & NA \\
1994 & 14 & 13.65 & 15.76 & NA & NA \\
Total & 143 & 16.32 & 20.22 & 6.410 & 15.72 \\
\hline
\end{tabular}

\section{Exhibit 3}

\section{Initial-day hospitality IPO returns}

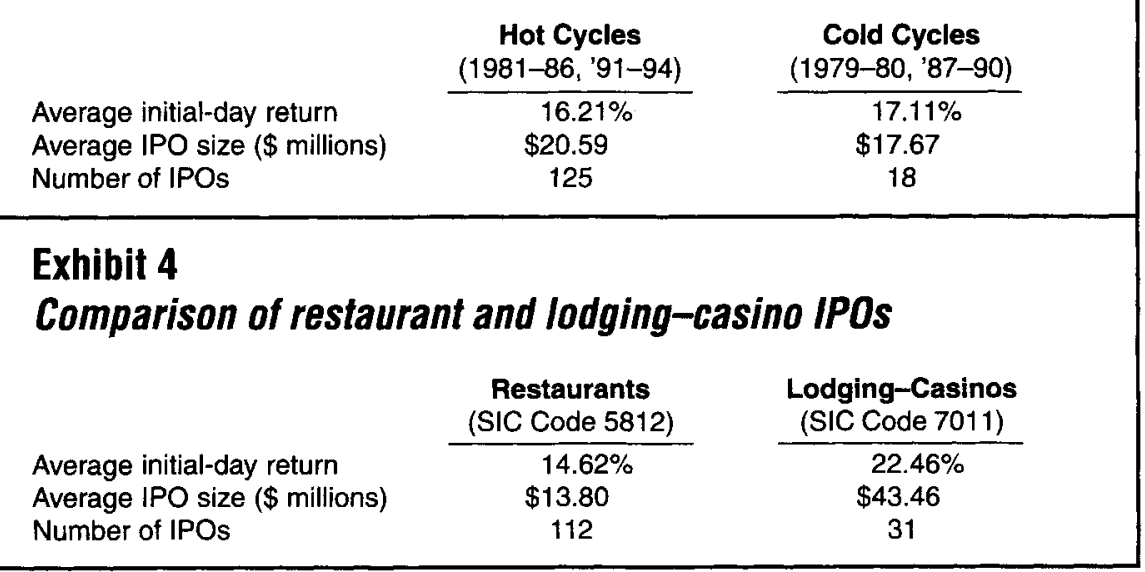




\section{Exhibit 5}

\section{Results of hospitality IPOs by segment}

\begin{tabular}{|c|c|c|c|c|c|c|}
\hline \multirow[b]{2}{*}{ Year } & \multicolumn{2}{|c|}{ Number of IPOs } & \multicolumn{2}{|c|}{$\begin{array}{c}\text { Average Initial-Day } \\
\text { Return } \\
\end{array}$} & \multicolumn{2}{|c|}{$\begin{array}{c}\text { Average IPO Size } \\
\text { (\$ millions) }\end{array}$} \\
\hline & $\begin{array}{c}\text { Lodging- } \\
\text { Casino }\end{array}$ & Restaurant & $\begin{array}{c}\text { Lodging- } \\
\text { Casino }\end{array}$ & Restaurant & $\begin{array}{c}\text { Lodging- } \\
\text { Casino }\end{array}$ & Restaurant \\
\hline 1979 & 2 & 1 & $86.50 \%$ & $-0.86 \%$ & $\$ 42.10$ & $\$ 11.60$ \\
\hline 1980 & 0 & 1 & - & 1.48 & - & 4.10 \\
\hline 1981 & 0 & 9 & - & 12.46 & - & 7.71 \\
\hline 1982 & 1 & 7 & 0.62 & 9.89 & 100.00 & 6.56 \\
\hline 1983 & 1 & 16 & 8.33 & 9.95 & 60.00 & 11.66 \\
\hline 1984 & 1 & 7 & 0.00 & 6.06 & 51.00 & 11.24 \\
\hline 1985 & 3 & 5 & 4.91 & 11.73 & 14.80 & 5.80 \\
\hline 1986 & 2 & 9 & 8.56 & 15.64 & 10.35 & 4.66 \\
\hline 1987 & 0 & 3 & - & -0.57 & - & 21.77 \\
\hline 1988 & 1 & 1 & 100.00 & 15.38 & 2.00 & 5.20 \\
\hline 1989 & 1 & 5 & 35.42 & -0.80 & 3.00 & 22.46 \\
\hline 1990 & 1 & 2 & -18.75 & 4.01 & 3.50 & 13.40 \\
\hline 1991 & 1 & 9 & 75.00 & 15.35 & 12.00 & 29.32 \\
\hline 1992 & 4 & 13 & 24.96 & 15.85 & 43.32 & 19.83 \\
\hline 1993 & 8 & 15 & 13.34 & 36.39 & 83.78 & 16.60 \\
\hline 1994 & 5 & 9 & 8.84 & 16.33 & 24.60 & 10.84 \\
\hline
\end{tabular}

\section{Exhibit 6}

\section{Effects of hot and cold cycles on hospitality IPOs}

\begin{tabular}{l|c|c|c|c|c} 
& \multicolumn{2}{c|}{ Lodging-Casino IPOs } & \multicolumn{2}{c}{ Restaurant IPOs } \\
\cline { 2 - 3 } & Hot Cycle & Cold Cycle & & Hot Cycle & Cold Cycle \\
\cline { 2 - 3 } \cline { 5 - 6 } Average initial-day return & $17.10 \%$ & $28.96 \%$ & $16.36 \%$ & $1.40 \%$ \\
Average IPO size (\$ millions) & $\$ 56.85$ & $\$ 27.20$ & $\$ 13.33$ & $\$ 17.33$ \\
Number of IPOs & 17 & 14 & 99 & 13
\end{tabular}

\section{Exhibit 7}

\section{Underwriter prestige and hospitality IPO returns}

\begin{tabular}{lc|c|c|c|c|c} 
& \multicolumn{2}{c|}{ All hospitality } & \multicolumn{2}{c|}{ Lodging-Casinos } & \multicolumn{2}{c}{ Restaurants } \\
\cline { 2 - 7 } & $\begin{array}{c}\text { High } \\
\text { prestige }\end{array}$ & $\begin{array}{c}\text { Low } \\
\text { prestige }\end{array}$ & $\begin{array}{c}\text { High } \\
\text { prestige }\end{array}$ & $\begin{array}{c}\text { Low } \\
\text { prestige }\end{array}$ & $\begin{array}{c}\text { High } \\
\text { prestige }\end{array}$ & $\begin{array}{c}\text { Low } \\
\text { prestige }\end{array}$ \\
\cline { 2 - 7 } & $16.81 \%$ & $15.99 \%$ & $18.22 \%$ & $26.98 \%$ & $16.27 \%$ & $13.63 \%$ \\
Initial return & $\$ 36.61$ & $\$ 9.05$ & $\$ 66.94$ & $\$ 18.41$ & $\$ 25.05$ & $\$ 7.04$ \\
IPO size (\$millions) & $\$ 36.65$ & 16 & 15 & 42 & 70
\end{tabular}

average initial returns (see Exhibit 6). This relationship does not hold for the lodging-casino firms. During hot cycles, the average initial return is lower than during the cold cycle. The average initial return during the hot cycle is 17.10 percent, but that return is 28.96 percent during the cold cycle. These results are not conclusive, since the hot cycle coincides with the industry's economic recovery. ${ }^{15}$ Notice that for lodging-casino firms, the level of underpricing consistently falls during the 19921994 period. The decline could be due to the market's increasing experience with IPOs in the industry or a reduction in uncertainty about the industry's future prospects.

\section{The Winner's Curse}

As I stated above, one of the implications of the winner's curse model is that as an issue's risk level increases so should the level of underpricing. Also as mentioned above, the most-prestigious investment bankers are associated with the least-risky IPOs. As a result, the more prestigious underwriters should be associated with less underpricing relative to the averages. The overall IPO market demonstrates this inverse relationship between the reputation of the underwriter and the level of underpricing.

For the hospitality IPOs in my sample, however, the reverse relationship holds, although the difference is not statistically significant. The more-prestigious underwriters underprice hospitality issues more than do the less-prestigious firms (as shown in Exhibit 7). The under-

\footnotetext{
${ }^{15}$ When the industry's recession was isolated as a separate period-with 1988-1991 defined as a cold cycle and 1979-1987 and 1992-1994 as hot cycles - the average initial returns were 47.92 percent for the cold cycle and 18.69 percent for the hot period.
} 
pricing of lodging-casino properties by prestigious underwriters, however, is significantly lower than for IPOs as a whole.

\section{Long-Run Performance}

A general characteristic of IPOs is their poor stock-price performance in the long run relative to the general market. ${ }^{16}$ That is, after the initial-day price run-up, IPOs as a group do not prosper. This phenomenon is not evident in the hospitality industry, however, as shown in Exhibit 8. Unlike the overall IPO market, IPOs in the hospitality industry outperform the S\&P 500 in the long run. For example, over a 250-day holding period, the average return on the sample of hospitality IPO firms was 14.11 percent higher than the S\&P 500 return.

Restaurants generally did better than lodging and casino firms, but both groups outperformed the market. The 250-day excess returns for restaurants was 14.96 percent, while that figure for lodging-casino firms is 10.24 percent.

Notice that the excess return for lodging-casino IPOs is less than that of restaurant issues but that lodgingcasino IPOs' underpricing is greater than that of restaurant stocks. This provides some evidence of a positive association between underpricing and performance over the 19791994 period.

The differences in the relationship between the degree of underpricing and long-run performance over the two time periods could be due to the difference in the proportion of IPOs underwritten by the more reputable investment banks over the two periods or to the recovery of the lodging-casino industry. Over the 1979-1994 period, 41 percent of the IPOs are repre-

\footnotetext{
16 See: Ibbotson, Sindelar, and Ritter (1994), pp. $66-74$.
}

\section{Exhibit 8 Initial-day and first-year excess returns for hospitality IPOS}

$\begin{array}{lcc} & \text { 250-day excess return* } & \text { Initial-day return } \\ \text { Hospitality } & 14.11 \% & 16.32 \% \\ \text { Lodging and casinos } & 10.24 & 22.46 \\ \text { Restaurants } & 14.96 & 14.62\end{array}$

"Excess return is the stocks' geometric return compared to that of the Standard and Poor's average of 500 stocks.

\section{Exhibit 9 \\ Underwriter prestige and excess return}

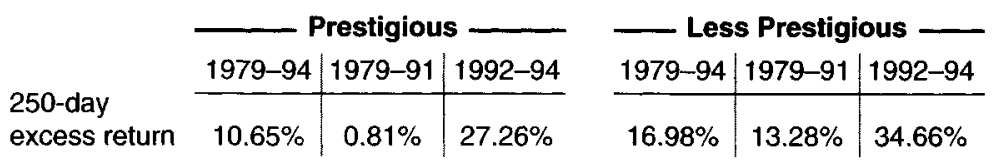

The excess return is the stock's geometric return that exceeds that of the S\&P 500 stocks. The prestigious underwriters are defined as the top 10 underwriters in terms of capital position.

sented by the top investment banks, but that figure rises to 52 percent during the 1992-1994 period. In an attempt to isolate these two factors, Exhibit 9 presents the 250-day excess return for prestigious and less prestigious investment banks for three time periods: 1979-1994, 1979-1991 and 1992-1994. The 250-day excess return is less for the more-reputable investment banks over the entire period and over each of the two subperiods. It is possible that the prestige of the investment bank is a proxy for the riskiness of the issue. Given that the more reputable investment banks underwrite less risky IPOs, the expected return should be lower, on average.

\section{Mixed News for Issuers and Investors}

Compared to the pricing of initial restaurant issues and the overall IPO market, underwriters generally underpriced lodging-casino stocks over the 1979-1994 period of my study. As for the IPO market as a whole, hospitality IPOs saw hot and cold cycles in both volume and the extent of underpricing, with a positive association between underpricing and number of issues for restaurants and a negative relationship between underpricing and the economic condition of the industry for lodging-casino stocks. For lodgingcasino stocks, the study's findings were in keeping with the concept that the prestige of the underwriter is a proxy for the riskiness of the issue. Specifically, the more prestigious underwriters discount the issues less than their less-wellknown competitors. Perhaps the most encouraging finding was that, unlike the overall IPO market, IPOs in the hospitality industry generally outperform the S\&P 500 in the first year after issue. That is favorable news for both the investors who wish a favorable return and for entrepreneurs who hope to sell their shares at a favorable price. Ca 